\title{
The Reproduction and Growth of the Pilchard.
}

\author{
By
}

\section{J. T. Cunningham, M.A.}

With Plate $\mathrm{X}$.

IN my paper on the Reproduction of Fishes occurring at Plymouth, published in this Journal, vol. i, p. 10, 1889, I identified as the egg of the pilchard, a pelagic egg commonly found in the tow-net in summer, and distinguished by three obvious characters, namely: (1) an unusually large perivitelline space; (2) a single large oil-globule in the vitellus; (3) a completely subdivided yolk. I also stated that ripe spawning pilchards occurred off Plymouth between June and October, but always at some distance from land, being usually taken in mackerel nets worked to the south of the Eddystone. My identification of the egg, taken in the sea, was founded upon a comparison between it and the eggs pressed from the ripe but dead female pilchards obtained from mackerel fishermen. The latter eggs were already dead, and did not float, but sank in sea water, but they possessed a single oil-globule, and the yolk in them consisted of a number of yolk-spheres. The large perivitelline space was absent, because it is only formed when living eggs are extruded into sea water.

Raffaele had previously described two kinds of pelagic eggs found at Naples, which he recognised, from their divided yolk and the characters of the larvæ hatched from them, as belonging to some species of Clupeoid. The larger of these eggs he attributed to Clupea pilchardus, but did not give his reasons. This egg is in all respects similar to that identified as belonging to the pilchard by myself at Plymouth. It is well known that the sardine of the French coast and of the Mediterranean is the same species of fish as the pilchard of Devon and Cornwall.

The natural history of the sardine has been investigated in recent years by two distinguished zoologists in France, namely, by Professor 
G. Pouchet, who is Director of a marine laboratory at Concarneau, on the coast of Brittany, and by Professor Marion, who has a similar laboratory at Marseilles.

The first publication in which Pouchet mentions the mature egg of the sardine is a note in the Comptes Rendus of the French Académie des Sciences, tome cix, No. 3 (July 15th, 1889). He states there that the sardine de rogue is a young sardine which is not yet full grown, and which has not yet spawned; while the sardine de dérive is alone adult, and alone sometimes contains mature ova. The explanation of these French terms, applied to sardines of different sizes on the French coast, is as follows:- Rogue is the name given by the French fishermen to a preparation of cods' roe which they throw into the water as a bait to attract the sardines. After the bait is thrown overboard a seine is shot round the place, and the sardines thus enclosed. Sardines de rogue are thus sardines caught by means of rogue and seine. Dérive, on the other hand, means drift, and sardines de dérive are those caught in drift-nets.

Pouchet proceeds to briefly describe the ripe ova taken from large sardines. He says they measure 1.20 to $1.30 \mathrm{~mm}$. in diameter; that they are transparent, heavier than sea water, and in the latter fall rapidly to the bottom. He says that there is little probability that the fertilized egg would behave differently, although some have supposed that it does. In any case, he says, he and his colleagues have never found this egg at the surface of the sea in the Bay of Concarneau. According to the same paper the vitelline membrane of the sardine's egg is smooth at its outer surface, but on its inner surface presents a reticulation of projecting ridges. The membrane consists of two layers, an external very thin and very refringent, and an internal thicker layer. The vitellus is granular and filled entirely with clear spheres, and with a single oil-globule of a pinkish colour. The paper concludes by insisting that the irregularity in the condition of the ovaries in the sardines de rogue indicates that the reproduction of the species is not subject to the influence of the seasons, but, like the greater part of the existence of the species, is carried in waters whose temperatures are nearly constant, that is in regions beyond the reach of man.

It is evident that, apart from the vitelline membrane, Pouchet does not differ from me as to the structure of the ripe egg of the pilchard; and as he has never seen the fertilized egg, it is somewhat hazardous on his part to argue that it does not float. The note above cited was published subsequently both to my paper and Raffaele's, so that it must be presumed that Pouchet attaches little weight to our evidence.

In his Report on the Concarneau Laboratory for 1889 presented to the French Minister of Public Instruction, and reprinted in the 
Journal d'Anatomie et de Physiologie, December, 1890, Pouchet again discusses the history of the sardine. He refers to the note I have criticised above, saying that in it he made known for the first time the ripe egg of the sardine. The assertion is the more surprising because in a note on the same page he refers to my paper published in this Journal in March, 1889, four months before his own, and containing both a description and figure of the ripe ovum taken from the fish. In this foot-note Pouchet remarks that I made no reference to the structure of the vitelline membrane, which alone could justify an identification of the egg. He refers to a detailed description of the ripe ovarian egg by M. Biétrix, one of his assistants, printed as an appendix to the Report. But strange to say M. Biétrix does not confirm Pouchet's results as to the peculiarities of the vitelline membrane. He finds, it is true, that the membrane consists of two layers, but he states that the ridges on the internal face of the membrane are not always present, and when present are very variable in appearance; they are generally present when the egg is taken from the ovary and disappear a few minutes afterwards. M. Biétrix thinks that these markings are perhaps due to an alteration of the membrane, the eggs having only been examined in sardines captured several hours before, and in a bad state of preservation. It is evident, therefore, that no importance in respect to identification is to be attributed to the vitelline membrane of the egg of the sardine. On the other hand, M. Biétrix, like Pouchet himself, fully confirms my description of the yolk and the single oil-globule.

Pouchet's most recent utterance on this subject is a note in the Comptes Rendus, dated April 6th, 1891. He tells us there that he has only twice in three years been able to observe ripe female sardines ready to spawn, namely May 29th, 1888, and April 3rd, 1890. It is evident, therefore, that Pouchet has not had many opportunities for studying the subject, the reason probably being that there is no fishing at Concarneau capable of capturing adult sardines, and carried on at a sufficient distance from the shore.

Professor Marion, at Marseilles, has published his observations on the sardine in the Annales du Musée de Marseille, 1890 and 1891. He finds that adult sardines are present in the Gulf of Marseilles all the year round. The sexual organs show no signs of enlargement till the beginning of October, and ripe specimens are seen from December till March, while some shoals have not spawned till the beginning of May. This result is in harmony with mine, for it is not surprising that the sardine should spawn in winter and spring in the warm waters of the Mediterranean, while it spawns in summer at Plymouth, and in both regions it appears that the spawning 
period is prolonged over five or six months, though the majority of the fish spawn within two months. Marion squeezed the ripe eggs from the fish into sea-water; the eggs on leaving the ovary were 1.3 to $1.4 \mathrm{~mm}$. in diameter, but after being in the water some hours the great perivitelline space had been formed, and the eggs were 1.7 to $1.8 \mathrm{~mm}$. in diameter, although they did not float. He remarks that this is no proof that eggs perfectly healthy, living and fertilized, do not float, while the vast perivitelline space establishes a great resemblance with the eggs attributed to the sardine, being a rare character in buoyant eggs. Marion also obtained in the Gulf floating eggs of the kind assigned by Raffaele and myself to the sardine, and found them only at the time of year when the sardines were ripe. Marion figures the egg and the larva hatched from it, pointing out that the latter is undoubtedly a clupeoid larva.

In the course of the past summer I made an attempt to finally set at rest the question of the pilchard egg by obtaining healthy fertilised ova from the parent fish by artificial fertilization. With this object I went out in a mackerel boat on June 21st, and on June 22nd the nets were shot about twenty miles to the south of the Eddystone, that is nearly thirty miles from the coast. When the nets were hauled I obtained in all about fifty ripe pilchards from them, but to my disappointment found there was not a single male among them. Probably the explanation of this is that the meshes of the net were rather large, and that the males are not quite so swollen when ripe as the females, and were, therefore, not retained. It must be pointed out that these ripe pilchards are not meshed by the gills in a mackerel net as the mackerels are, but are meshed round the abdomen, which is greatly distended by the swollen ovaries. Pilchard nets are never, so far as I know, used off Plymouth so far out at sea as spawning pilchards are found. In fact, very little pilchard fishing is carried on in June and July, and when it is recommenced in August and September it is carried on almost exclusively inside the Eddystone. (See Mr. Roach's records of pilchard fishing, this Journal, vol. i, p. 388.)

However, I squeezed some ripe eggs from the living female fish I obtained into a bottle of clean sea-water without delay, and when I examined them in the Laboratory a few hours afterwards I had the satisfaction of finding nearly all of them floating at the surface. These floating eggs were in all respects similar to the eggs identified as pilchard eggs obtained in the tow-net from the sea; they were perfectly transparent, the yolk in them consisted, not of yolk-spheres as in the dead ova from the ovary, but of polygonal masses, that is of yolk-spheres made polygonal by mutual pressure, as in the eggs obtained from the sea, the large oil-globule was present and the 
great perivitelline space was formed. These eggs measured $1 \cdot 2,1 \cdot 36$, $1.45 \mathrm{~mm}$. in diameter, that is, the perivitelline space was not quite so large as in fertilised eggrs, but this is not surprising. The experiment proves conclusively that the ripe eggs of the pilchard, when pressed from the parent fish immediately it is captured, do actually float in sea water, become transparent, and develop a large perivitelline space.

Professor Pouchet makes an appeal to his Government to provide a suitable ship in order to discover where the sardine passes its existence when away from the coast, and reproduces its kind. He thinks the objects of the search would be found within 200 or 300 miles from the shore. He rejects the results of Marion's observations at Marseilles, because what is true for the sardine of the Mediterranean does not apply to the oceanic sardine. But, as Marion points out, the mode of reproduction of the sardine has been made known at Plymouth, and the conditions cannot be so very different a few miles off at Concarneau.

2. Growth.-The sardine of the Mediterranean is not so large as our pilchard or the sardine of the west coast of France-the oceanic sardine, as Pouchet aptly calls it. At Marseilles the adult sardines are $15 \mathrm{~cm}$. to $18 \mathrm{~cm}$. in length, or 6 to $7 \frac{1}{4}$ inches. Pouchet finds that the sardines de dérive attain a maximum of $25 \mathrm{~cm}$. or even a little more, that is they are from $9 \frac{1}{2}$ to 10 inches long. The ripe spawning pilchards which I obtained this summer did not vary much from $24 \mathrm{~cm}$. or $9 \frac{1}{2}$ inches.

At Marseilles and Nice the alevins or fry of the sardine are captured for the market, as whitebait, the fry of the herring and sprat, are in England. The sardines remain and are captured in the Gulf of Marseilles during the whole of the first year of their life, and Marion finds from examination of specimens at various times of the year that they increase in length $1 \mathrm{~cm}$. per month. The fishermen of Nice give special names to the successive stages in the development of the sardine, thus the young fish from 2 to 4 centimetres long without the silvery layer in the skin are called poutino nudo, while at a little larger size, 4 to 5 centimetres, when they have acquired the silvery livery they are called poutino vestido. When still larger they are called Palailla and Sardinettes. Marion concludes that poutines which are 3 or $4 \mathrm{~cm}$. long $(1 \cdot 2-1.6$ in.) in March grow to a length of 12 or $13 \mathrm{~cm}$. $(4 \cdot 7-5 \cdot 1$ in.) by the following December. These fish were spawned in February, and by the following February according to Marion they are 14 or $15 \mathrm{~cm}$. long, and therefore, it would be supposed, ready to spawn themselves. Professor Marion does not express any opinion on this point, but it would certainly appear from his conclusions as to the rate of growth that the 
sardine at Marseilles begins to spawn when it is one year old, although it probably does not reach the maximum size of $18 \mathrm{~cm}$. ( $7 \frac{1}{4}$ in.) till it is at least two years old.

At present we have scarcely any evidence as to the growth of the pilchard or oceanic sardine. Pouchet tells us that the smallest sardine he has hitherto obtained was $9.8 \mathrm{~cm}$. in length or 3.9 inches, and he thinks this was about six months old. At Plymouth I have not yet obtained the young of the pilchard at various successive stages. Our fishermen never seem to catch pilchards so small, and, therefore, presumably, so young as the fish taken for the sardine industry on the French coast. I believe this difference is due chiefly to the character of the nets used, the drift-nets at Plymouth having too large a mesh to retain the young fish. However I believe I have obtained some of the very early stages of the young pilchard. The specimens I refer to were taken in the same hauls of the large tow. net as the Phyllosoma I have described in another paper, that is to say they were obtained at the surface on July 9 th and July 16 th, about two miles north and south of the Eddystone. I have figured three of these specimens illustrating different stages of development. The smallest and youngest stage represented in fig. 1 is $8.5 \mathrm{~mm}$. in length; the larval membranous fin is still present along the dorsal edge and behind the anus ventrally, the permanent dorsal fin is beginning to develope and a symmetrical larval tail fin is present supported by slender rays. All the figures have been drawn from preserved specimens mounted in Canada balsam, and this is the reason of their somewhat rough character, the mounted specimens having lost the transparency and sharpness of detail seen in living fish-larvæ. The notochord in the stage shown in fig. 1 is a large and conspicuous structure. Fig. 2 represents a slightly more advanced stage in which the development of the fin-rays of the dorsal fin is more pronounced, and there is an indication of the permanent caudal fin-rays on the ventral side of the notochord in the tail. The actual size of the specimen from which this figure was drawn is $11.5 \mathrm{~mm}$. The specimen represented in fig. 3 is $2.4 \mathrm{~cm}$. long, and is in the same stage as the fish called at Nice poutino mudo. All trace of the primordial fin-membrane has disappeared, and the permanent fin-rays are almost completely developed in the dorsal fin, ventral fin, and caudal fin. The pelvic fins have also appeared; the pectorals are present in the earlier stages, but in this stage are larger, and their fin-rays are beginning to develop. The dorsal fin at this stage is some distance behind the pelvic, while in the adult its anterior extremity is in front of the pelvic.

That these young clupeoids are not herring larvæ is proved by 


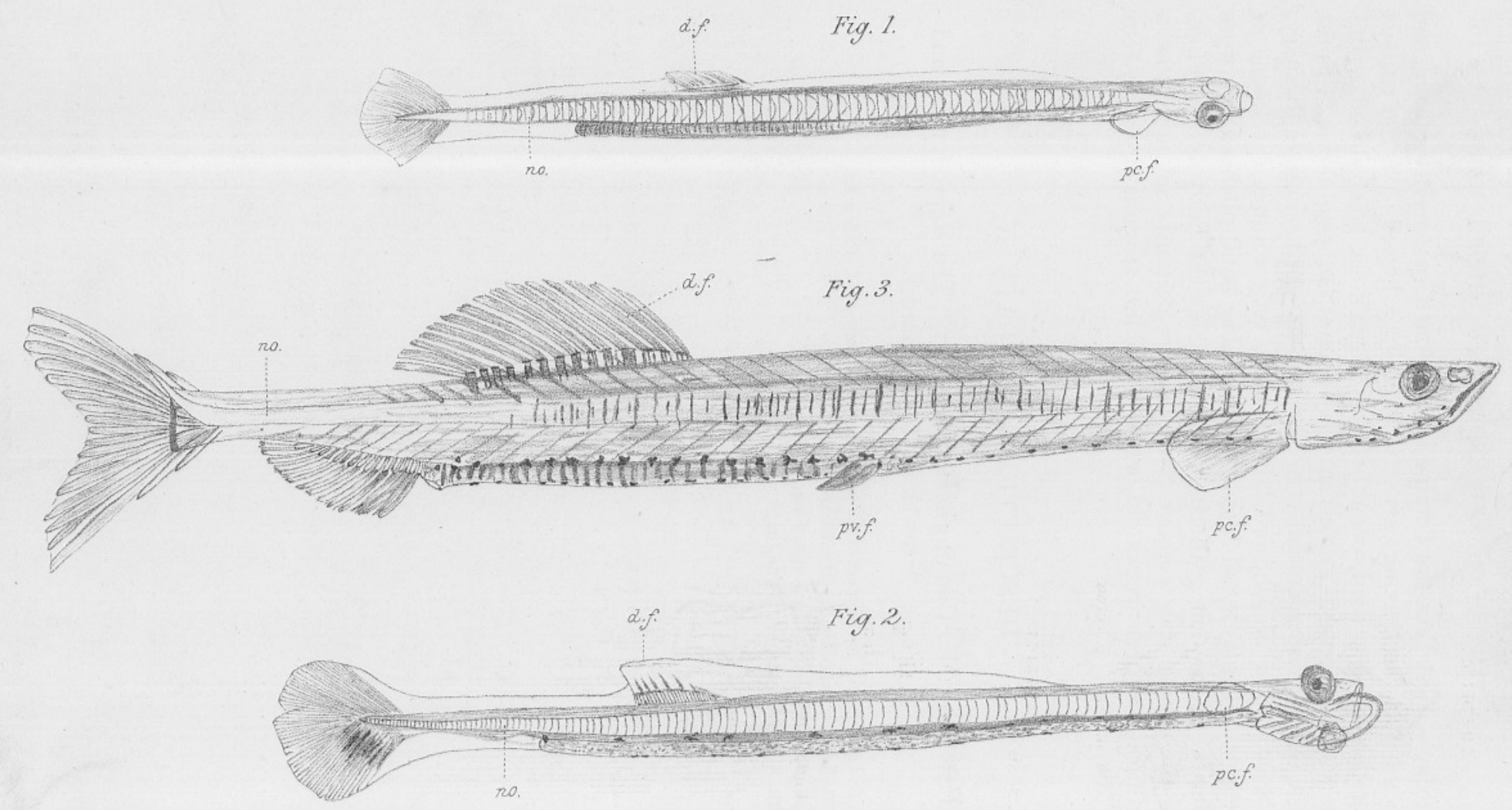


two facts, first that the herring at Plymouth spawns in January, and second that the herring larva is $9 \mathrm{~mm}$. long, larger than the earliest stage above described, even before the yolk-sac is absorbed. But it is more difficult to prove that they cannot be sprat larvæ. Sprat eggs occur most plentifully in the tow-net gatherings in January, February, and March, and I have taken only solitary specimens as late as the beginning of May. On the other hand pilchard ova were plentiful in tow-net gatherings taken outside the Eddystone in June, and the earlier stages above described are certainly not more than a fortnight or three weeks old, while the oldest stage is probably four or five weeks.

\section{DESCRIPTION OF PLATE $\mathrm{X}$,}

Illustrating Mr. Cunningham's paper on "The Reproduction and Growth of the Pilchard."

d.f. Dorsal fin. no. Notochord. pc.f. Pectoral fin. pv.f. Pelvic fin.

Frg. 1.-Larva, probably of pilchard, $8.5 \mathrm{~mm}$. long.

Fig. 2.-Older larva, $11.5 \mathrm{~mm}$. long.

FIG. 3.-Later stage, $2 \cdot 4 \mathrm{~cm}$. long. 